\title{
PROSPEK VAKSIN POLIVALEN UNTUK PENCEGAHAN PENYAKIT POTENSIAL PADA PERIKANAN BUDIDAYA
}

\author{
Angela Mariana Lusiastuti dan Taukhid \\ Balai Riset Perikanan Budidaya Air Tawar \\ Jl. Raya Sempur No. 1, Bogor 16154 \\ E-mail: lusiastuti@ yahoo.com
}

\begin{abstract}
ABSTRAK
Perkembangan vaksin pada ikan masih dalam tahap penelitian. Rencana strategis untuk pengembangan vaksin oleh peneliti merupakan pola dari riset yang dilakukan. Identifikasi antigen yang bersifat protektif, metode untuk produksi antigen protektif dalam kultur mikroba, metode bagaimana merubah bentuk antigen protektif menjadi bersifat imunogenik, merupakan tiga tahap yang dilakukan dalam riset tentang vaksin. Vaksin polivaleni adalah bentuk vaksin generasi baru yang memberikan perlindungan terhadap dua atau tiga penyakit pada saat yang sama jika dibandingkan dengan aplikasi satu atau dua vaksin secara terpisah. Keuntungan dari strategi ini adalah: sedikit jarum yang diinjeksikan, berkurangnya prosedur tata laksana, dan sumber daya manusia (SDM) yang digunakan. Dalam makalah ini juga dibahas keuntungan dan kerugian penggunaan vaksin polivalen serta tahap-tahap produksi vaksin tersebut.
\end{abstract}

KATAKUNCl: vaksin polivalen, keuntungan dan kerugian, budidaya ikan

\section{PENDAHULUAN}

Pengendalian penyakit yang disebabkan oleh infeksi patogen pada perikanan budidaya dengan menggunakan obat/antibiotik/bahan kimia telah banyak dilakukan, dan hal itu merupakan cara pengendalian yang popular karena dalam jangka pendek hasilnya sudah dapat dilihat. Tetapi apabila dilakukan dengan prosedur yang keliru, efek jangka panjangnya sangat mengkhawatirkan, terutama apabila penerapannya tidak sesuai dengan peruntukannya. Oleh karena itu, tindak pengobatan penyakit ikan harus didasarkan pada kaidah-kaidah yang benar.

Beberapa issue yang mulai berkembang berkenaan dengan penggunaan obat/antibiotik/bahan kimia pada perikanan budidaya:
(1) Pengaruh penggunaan zat aditif, antibiotik, hormon, desinfektan dan bahan kimia lainnya pada proses produksi ikan terhadap lingkungan perairan,

(2) Pengaruh akumulasi residu obat/antibiotik pada produk perikanan (terutama consumption products) terhadap kesehatan konsumen;

(3) Berkembangnya resistensi patogen terhadap obat/ antibiotik, yang terjadi akibat penggunaan satu jenis antibiotik yang selalu berulang-ulang dan kurang terkendali.

Program vaksinasi pada perikanan budidaya telah terbukti memberi kontribusi yang sangat signifikan terhadap peningkatan produksi perikanan budidaya, terutama industri salmon dan trout di Eropa (Nestor et al., 2006). Saat ini, sedikitnya ada 10 jenis vaksin yang telah dipasarkan secara umum dan diaplikasikan oleh pembudidaya ikan di Amerika, Eropa, dan Jepang. Keberhasilan program vaksinasi tersebut, hal itu terlihat dari (1) menurunnya tingkat mortalitas ikan budidaya akibat infeksi patogen potensial, (2) menurunnya penggunaan antibiotik pada budidaya ikan, dan (3) menurunnya daya resistensi beberapa jenis patogen terhadap antibiotik.

Pengembangan vaksin untuk ikan umumnya didasarkan pada penggunaan bakteri patogen yang diinaktivasi, dan sediaan vaksin tersebut telah terbukti sangat efektif untuk menginduksi kekebalan spesifik pada tubuh ikan. Sangat sedikit vaksin komersial untuk penyakit viral pada ikan, dan belum ada vaksin untuk penyakit ikan yang disebabkan oleh patogen parasitik.

Sepanjang sejarah manusia dan hewan, vaksin digunakan untuk mencegah penyakit epidemi dan secara signifikan mengurangi morbiditas dan mortalitas penyakit menular baik pada hewan maupun manusia. Selama bertahun-tahun organisasi kesehatan dunia, World Health Organization (WHO), The United Nations Children's Fund (UNICEF), dan Global Alliance for Vaccines and Immunization (GAVI) mendiskusikan diluncurkannya vaksin polivalen (polyvalent vaccine) sebagai bentuk vaksin generasi baru yang memberikan proteksi terhadap 3-5 jenis penyakit 
sekaligus (David, 2008). Sebagai contoh pada manusia, vaksin Tetravalent yang memberikan proteksi terhadap difteri, tetanus, pertussis dan hepatitis B (DPT-HB) dan vaksin Pentavalent yang terdiri atas Tetravalent dikombinasi dengan Haemophilus influenza tipe B (DPTHB-Hib). Salah satu vaksin polivalen untuk ikan yang sudah dikaji adalah kombinasi antara bakteri Vibrio anguillarum dan Pasteurella piscicida untuk ikan seabass (David, 2008)

Vaksin polivalen merupakan campuran dari dua atau lebih vaksin yang diberikan pada saat dan lokasi anatomi yang sama. Vaksin tidak membunuh patogen, tetapi hanya membantu sistem imun inang untuk proteksi melawan penyakit menular dan berbahaya secara efektif. Jadi, vaksin akan efektif jika inang mempunyai sistem imun. Krustase (udang), moluska (kekerangan), dan tanaman akuatik (rumput laut) tidak dapat divaksinasi karena tidak mempunyai sistem imun spesifik (adaptif).

Pada tahun 1970-an, beredar vaksin imersi dari kultur cair yang diinaktivasi menggunakan formalin terhadap Vibrio pada ikan salmon. Pada awal 1990 -an, vaksin injeksi berisi ajuvan digunakan untuk proteksi terhadap Aeromonas salmonicida penyebab Furunculosis pada ikan. Pada tahun yang sama, beberapa produsen vaksin ikan dunia sudah mendominasi pasar seperti Norwegian Pharmaq, Swiss Novarks Animal Health dan US Based Schering Plough Animal Health. Pangsa pasar vaksin ikan dunia terutama untuk industri ikan salmon, trout, dan catfish; serta dalam skala yang lebih kecil untuk jenis ikan european seabream, seabass, dan tilapia (Nestor et al., 2006).

Peneliti dari ARS Aquatic Animal Health Research Unit di Auburn, Alabama telah menemukan dan mematenkan beberapa jenis vaksin ikan, dan rata-rata diperlukan waktu penelitian selama 2-4 tahun untuk menemukan satu jenis vaksin. Sedangkan untuk dapat memperoleh vaksin tersebut di pasaran membutuhkan waktu 5 tahun kemudian, sehingga untuk memperpendek waktu tersebut peneliti diharapkan dapat bekerja sama dengan industri yang dapat mengembangkan dan menguji vaksin tersebut. ARS sudah mematenkan modified live vaccine terhadap Flavobacterium columnare. Bakteri ini menyebabkan penyakit Columnaris, penyebab kematian kedua pada catfish setelah penyakit Enteric Septicaemia of Catfish (ESC) yang disebabkan oleh bakteri Edwardsiella ictaluri. Vaksin ini diharapkan dapat menghemat 100 juta dolar per tahun untuk terapi, penggunaan bahan kimia desinfektan pada air dan pemberian pakan khusus (Nestor et al., 2006).

Balai Riset Perikanan Budidaya Air Tawar - Pusat Riset Perikanan Budidaya telah mengembangkan vaksin antiAeromonas hydrophila dengan nama HydroVac sebagai salah satu produk biologi bagi upaya pencegahan penyakit M otile
Aeromonas Septicemia (MAS) akibat infeksi bakteri Aeromonas hydrophila, yang merupakan salah satu patogen potensial pada semua jenis ikan budidaya air tawar. Hasil kajian laboratoris dan lapang terhadap efikasi vaksin tersebut diketahui bahwa vaksin HydroVac mampu menekan tingkat kematian ikan akibat penyakit MAS antara 30\%40\% dibandingkan dengan tanpa aplikasi vaksin yang mencapai $60 \% 70 \%$ Saat ini, vaksin tersebut sedang dalam proses pengajuan Hak Kekayaan Intelektual (HAKI) untuk memperoleh paten. Menyusul kemudian, vaksin anti-Streptococcus dan M ycobacterium yang masih dalam kajian riset (2009-2014); kedua jenis patogen tersebut juga merupakan patogen utama pada budidaya ikan air tawar.

\section{KEUNGGULAN VAKSIN POLIVALEN}

Beberapa keunggulan dari vaksin polivalen pada perikanan budidaya menurut Nestor et al. (2006), antara lain:

1. Memberikan proteksi lebih dari satu jenis penyakit potensial yang disesuaikan dengan jenis inang dan patogen spesifik, bahkan mungkin dapat didasarkan pada kawasan endemik penyakit tertentu.

2. Mengurangi keterpaparan terhadap ajuvant yang berisiko untuk terjadinya nyeri sampai shock pada hewan atau manusia, apabila diberikan melalui injeksi. Contoh: DTaP, IPV, Hib, dan/atau HB membutuhkan 0,7 mg garam aluminium, sedangkan apabila dalam bentuk vaksin polivalen DtaP, IPV, Hib dan HB hanya dibutuhkan sebanyak 1,75 mg garam aluminium.

3. Mengurangi keterpaparan terhadap preservatif thimerosal, yang sejatinya bersifat toksik terhadap hewan atau manusia, termasuk ikan.

4. Mengurangi stres pada ikan yang hendak divaksin karena dengan sekali aplikasi sudah mampu menginduksi kekebalan terhadap beberapa jenis penyakit. Terlebih lagi pada vaksin yang harus diberikan melalui injeksi, maka sediaan vaksin ini akan mengurangi jumlah injeksi.

5. Memperpendek waktu kunjungan (visit).

6. Mengurangi biaya transportasi dan penyimpanan vaksin.

\section{KEKURANGAN VAKSIN POLIVALEN}

Beberapa kekurangan dari vaksin polivalen pada perikanan budidaya menurut Nestor et al. (2006), antara lain:

1. Dalam proses pengembangannya perlu chemical trials sehingga perlu proses dan waktu yang lebih lama 


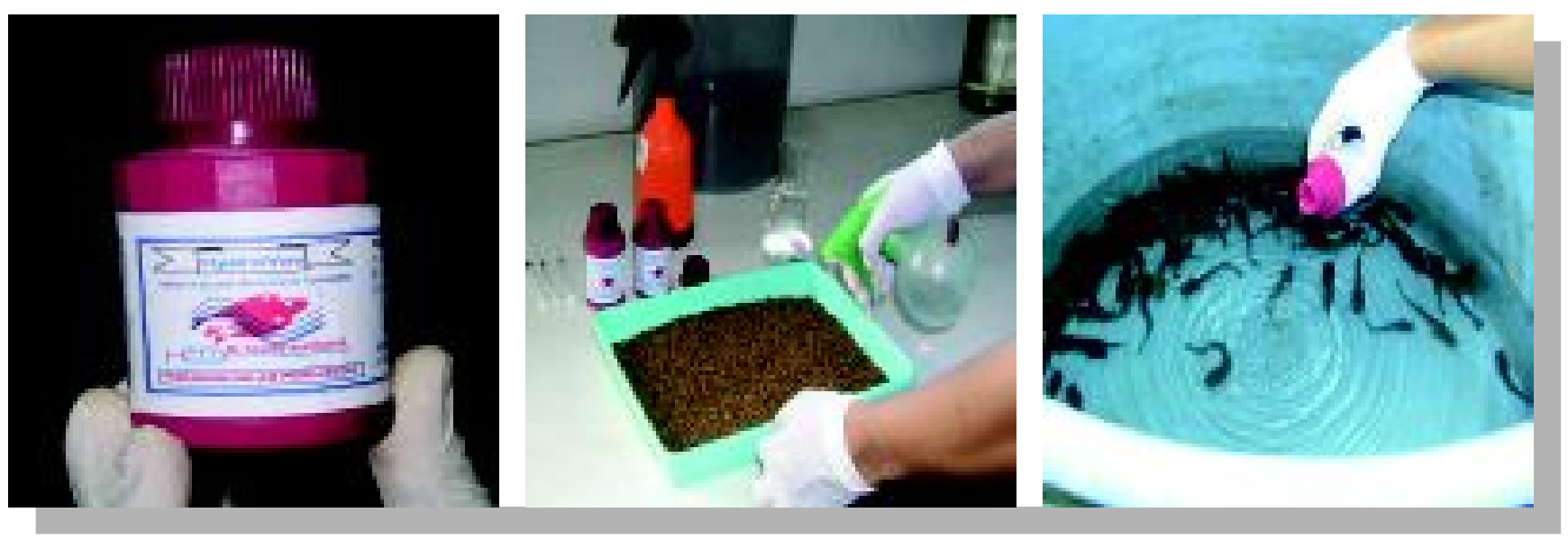

Gambar 1. Vaksin HydroVac produksi Balai Riset Perikanan Budidaya Air Tawar di Bogor yang diaplikasikan melalui per oral dan perendaman

(kompleksitas proses produksi), serta biaya produksi yang tinggi sehingga harga sediaan vaksin polivalen tentunya akan lebih mahal dibandingkan sediaan vaksin monovalen.

2. Kondisi yang kompatibel secara fisik, kimiawi dan biologis perlu dipertimbangkan antara komponen aktif, ajuvant, dan bahan-bahan penyerta lainnya karena dapat terjadi inkompatibilitas antar komponen.

3. Mode of action dari masing-masing antigen penyusun vaksin polivalen dapat saling mengganggu satu sama lain (antagonistic) sehingga dapat mengurangi potensi satu atau kedua komponen. Gangguan bisa bersifat fisik, seperti mencari suhu maksimum untuk potensi optimal dari gabungan beberapa komponen, gangguan kimiawi seperti jenis ajuvan, preservatif, inaktivator atau stabilizers yang berbeda, ataupun dari sifat antigen yang tidak stabil.

4. Jika terjadi alergi, lebih sulit bagi vaksin polivalen untuk mengidentifikasi komponen mana yang merupakan penyebab utama (spesifik).

\section{STRATEGI FORMULASI}

Faktor-faktor yang berkaitan dengan vaksin menurut Ellis (1988) adalah, (1) dosis antigen, tingkat produksi antibodi pada respons imun primer biasanya berkorelasi dengan dosis antigen yang diberikan. Untuk menginduksi memori, selain dosisjuga tergantung kepada kealamiahan antigen; bentuk antigen sangatlah penting, antigen dari protein soluble lebih baik diaplikasikan bersamaan dengan ajuvant untuk meningkatkan produksi antibodi. Sebagai contoh, bovine serum albumin (BSA) dalam Complete Freund's adjuvant akan bersifat imunogenik jika diinjeksikan ke carp, tidak jika diinjeksikan dalam saline kecuali jika ikan tersebut dinjeksi terlebih dahulu dengan antigen dalam ajuvan. Sifat imunogenisitas antigen bervariasi antar spesies ikan. BSA tanpa ajuvan adalah imunogen yang baik bagi tilapia, tetapi merupakan imunogen yang sangat buruk untuk rainbow trout walaupun jika diinjeksikan dengan ajuvan. Eritrosit kuda adalah imunogen yang baik bagi winter flounder, tetapi tidak untuk eritrosit domba, walaupun eritrosit domba adalah imunogen yang sangat baik untuk carp;

Faktor ke (2) menurut Ellis (1988) adalah cara pemberian, vaksinasi oral dalam pakan merupakan metode vaksinasi ideal pada ikan. Tetapi beberapa penelitian melaporkan adanya respons yang buruk dan tidak konsisten akibat kerusakan antigen pada saluran cerna. Pendekatan yang dilakukan untuk melindungi antigen dari proses degradasi adalah menyelubungi antigen dalam liposom atau al ginat, menetralisasi sekresi asam lambung atau aplikasi vaksin melalui biofilm. Vaksin secara per oral memerlukan antigen dalam jumlah besar dan proteksi yang ditimbulkannya lemah dan hanya dalam waktu yang singkat. Selain per oral, metode vaksinasi yang lain adalah imersi yang efektif untuk bakteri, lebih murah dan mudah dilakukan pada ikan ukuran kecil. Vaksinasi secara injeksi lebih efektif untuk ikan ukuran tertentu dan sulit dilakukan pada benih. Beberapa peneliti melaporkan bahwa injeksi antigen IM lebih merangsang terbentuknya titer antibodi yang tinggi dibandingkan dengan injeksi IP. Carp yang diinjeksi IM dengan eritrosit domba menunjukkan adanya memori yang lebih baik dibanding via intravena. Soluble BSA yang diinjeksi intrakardial pada carp akan merangsang toleransi terhadap antigen untuk jangka waktu lebih dari 16 bulan.

Sistem imun mempunyai bagian-bagian yang terpisah, yaitu sistemik dan mukosal. Mukosal dibagi lagi menjadi integumentary dan alimentary. Rute stimulasi antigen 
merupakan efek penting di setiap bagian tersebut; Keuntungan vaksin injeksi yaitu volume yang dibutuhkan relatif sedikit dan ikan dapat divaksin dengan dosis yang tepat;

Faktor ke (3) menurut Ellis (1988) adalah ajuvan, adalah substansi yang dapat meningkatkan respons imun. Respons imun humoral, khususnya sel T dapat dirangsang dengan pemberian antigen yang diberi ajuvan. Banyak ajuvan karena bentuk alamiahnya, hanya diaplikasikan melalui injeksi.

Untuk menuju ke strategi formulasi, perlu mengidentifikasi antigen protektif sehingga metode untuk mengoptimalkan ekspresi antigen dapat dikembangkan. Lebih dari satu antigen dapat bersifat protektif, dan beberapa antigen dapat menstimulasi beberapa bagian dari sistem imun yang lebih besar dari yang lain sehingga perlu seleksi strain sebagai kandidat vaksin yang akan diberikan secara oral, imersi atau injeksi karena potensinya bisa berbeda-beda. Determinasi antigen dapat menggunakan kombinasi antara gel elektroforesis dan teknik blotting. Keputusan awal yang diambil dalam pembuatan vaksin berdasarkan determinasi antigen secara serologis, komposisi strain dan apakah subtipe antigen berkorelasi secara geografis atau dalam spesies ikan (Pasnik et al,, 2005).

\section{UJI POTENSI}

Setiap batch vaksin harus memenuhi standar minimum uji potensi untuk persetujuannya (approval). Ikan divaksinasi dan dilakukan uji tantang (imersi atau injeksi) dan mortalitasnya dibandingkan dengan ikan kontrol tanpa divaksinasi. Metode yang dianjurkan adalah menghitung nilai potensi yang disebut sebagai Relative Percent Survival (RPS) (Sommerset et al., 2005). Selain itu, juga dianjurkan untuk mengkonfirmasi virulensi melalui eksperimen sebelum uji potensi batch, hal ini untuk memastikan bahwa kultur master seed baik untuk uji tantang dan produksi disimpan dengan baik dan sesuai dengan protokol, serta frekuensi subkultur telah didefinisikan dan disetujui dengan benar. Baik metodologi dan uji batch dibutuhkan untuk persetujuan vaksin. Ujiuji yang dilakukan harus di audit oleh badan independen untuk memastikan telah dilakukan Good Laboratory Practice dan semuanya sudah dicatat pada setiap level prosesing sampai produk akhir (Sommerset et al., 2005).

Uji-uji tersebut menurut Sommerset et al. (2005) adalah sebagai berikut:

- Uji Imunogenisitas, uji ini bertujuan membandingkan hasil respons imun dalam melawan antigen yang diukur melalui titer antibodi. Dilakukan dengan cara injeksi strain vaksin yang diuji, dengan menggunakan pembanding berupa material reference dan placebo.

- Uji Potensi, tujuan dari uji ini adalah untuk mengetahui stabilitas vaksin yang telah diformulasi dan disimpan pada suhu tertentu. Studi stabilitas dilakukan pada periode waktu 6 bulan, setelah itu dicek kembali untuk periode 12 bulan. Sampel vaksin dievaluasi dengan parameter fisika, kimia dan biologis. Kisaran lama studi biasanya adalah 30 bulan. pH, konsentrasi alumina, thimerosal dan formaldehid dapat diperiksa karena mempengaruhi karakteristik organoleptis dari vaksin. Faktor-faktor tersebut dapat mempengaruhi pembentukan gumpalan (clots), turbiditas atau perubahan pada warna vaksin. Uji stabilitas pada kurun waktu 30 bulan dapat dilakukan dengan uji sterilitas untuk mengetahui apakah sistem pengepakan dan mekanisme closing sudah cukup aman untuk preservasi produk.

- Uji Pre-Klinis, uji ini bertujuan untuk mengetahui reaktogenisitas vaksin polivalen dengan cara inokulasi pada dosis tinggi melalui IM Ialu diamati selama 14 hari untuk mengetahui adanya gejala toksisitas atau kematian dari hewan coba. Evaluasi yang dilakukan adalah toksisitas akut dan toleransi lokal. Evaluasi bisa juga dengan menggunakan tiga dosis yaitu dosis rendah adalah 15 kali dosis yang digunakan pada studi klinis, dosis sedang 30 kali dosis klinis dan dosis tinggi 60 kali dosis klinis. Untuk dosis tinggi, total volume dibagi untuk diaplikasikan pada kedua sisi dari hewan coba.

- Clinical Trials, Uji klinis dilakukan dalam dua fase: fase I adalah evaluasi safety atau reaktogenisitas vaksin dan fase II untuk mengetahui imunogenisitas vaksin. Dua aspek dasar yang dievaluasi pada fase II dari studi klinis adalah: (1) \%seroproteksi atau fraksi antibodi yang bisa memproteksi terhadap antigen; (2) geometric mean dari titer antibodi setelah divaksin.

\section{PROSPEK VAKSIN PADA IKAN}

Akhir-akhir ini, vaksin untuk penyakit bakterial pada ikan sudah banyak tersedia di dunia. Vaksin bakterial komersial pertama adalah vaksin terhadap Enteric Redmouth Disease (ERM, Yersiniosis) dan Vibriosis, yang diluncurkan di USA pada akhir 1970-an (Nestor et al., 2006). Vaksin ini berdasarkan formulasi inaktivasi sel utuh dan aplikasinya secara imersi. Vibriosis terdistribusi secara global pada berbagai spesies ikan. Karakterisasi penyebab Vibriosis, Vibrio anguilarum, lebih dari 10 serotipe. Wabah Vibriosis pada salmonid dan cold water marine seperti Cod dan Halibut disebabkan oleh beberapa serotipe yang berbeda, sehingga vaksin yang didesain untuk salmonid otomatis tidak dapat digunakan untuk 
Tabel 1. Penyakit bakterial, viral, dan parasiter pada ikan dan tersedianya vaksin untuk ketiganya

\begin{tabular}{|c|c|c|c|}
\hline Jenis penyakit & Jenis ikan yang diserang & Lokasi kejadian & $\begin{array}{c}\text { Tersedianya } \\
\text { vaksin komersial }\end{array}$ \\
\hline \multicolumn{4}{|l|}{ Pen yakit bakterial: } \\
\hline Vibriosis (Vibrio spp.) & $\begin{array}{l}\text { Salmonid, Cod/Halibut, } \\
\text { Seabass/Bream, } \\
\text { Amberjack/Yellowtail }\end{array}$ & Global & Ada \\
\hline $\begin{array}{l}\text { Furunculosis } \\
\text { (Aeromonas salmonicida) }\end{array}$ & Salmonids & Eropa/Kanada/USA & Ada \\
\hline ERM/Yersiniasis & Salmonids & Eropa/Kanada/USA & Ada \\
\hline $\begin{array}{l}\text { Bacterial Gill Disease } \\
\text { (Flavobacterium branchiophilum ) }\end{array}$ & Salmonids, Carp, Ikan air tawar & Eropa/Kanada/USA & Tidak ada \\
\hline $\begin{array}{l}\text { Columnaris } \\
\text { (Flavobacterium columnare) }\end{array}$ & $\begin{array}{l}\text { Channel catfish, salmonids, } \\
\text { ikan air tawar }\end{array}$ & USA & Ada \\
\hline $\begin{array}{l}\text { Enteric Septicemia of Catfish } \\
\text { (Edwardsiella ictaluri ) }\end{array}$ & Catfish & USA & Ada \\
\hline Edwardsiella tarda & Catfish & Asia & Tidak ada \\
\hline $\begin{array}{l}\text { Lactococciasis } \\
\text { (Lactococcus garvieae) }\end{array}$ & $\begin{array}{l}\text { Rainbow trout, } \\
\text { Amberjack/Yellowtail }\end{array}$ & Eropa, UK, Jepang & Ada \\
\hline Streptococciasis (S. iniae ) & Tilapia & Asia & Ada \\
\hline \multicolumn{4}{|l|}{ Penyakit viral: } \\
\hline Infectious Pancreatic Necrosis & Salmonids & Global & Ada \\
\hline Viral Haemorrhagic Septicemia & $\begin{array}{l}\text { Rainbow trout, Turbot, } \\
\text { Japanese Flounder }\end{array}$ & Eropa, Asia & Tidak ada \\
\hline Iridoviral Disease & $\begin{array}{l}\text { Red Sea Bream, } \\
\text { Amberjack/Yellowtail }\end{array}$ & Asia & Ada \\
\hline Channel Catfish Virus Disease & Channel Catfish & USA & Tidak ada \\
\hline \multicolumn{4}{|l|}{ Penyakit parasiter: } \\
\hline Amoeba & Salmonids & $\begin{array}{l}\text { Eropa, Asia, } \\
\text { USA, Australia }\end{array}$ & Tidak ada \\
\hline Ichthyobodo spp. & Semua spesies & Global & Tidak ada \\
\hline White Spot Disease & Ikan air tawar & Global & Tidak ada \\
\hline Trichodina spp. & Semua spesies & Global & Tidak ada \\
\hline Gyrodactylus spp. & Semua spesies & Global & Tidak ada \\
\hline Dactylogyrus spp. & Semua spesies & Global & Tidak ada \\
\hline Benedinia spp. & Semua spesies & Asia Tenggara & Tidak ada \\
\hline Caligus & Semua spesies & Global & Tidak ada \\
\hline
\end{tabular}

Sumber: Sommerset et al., (2005)

spesies marine yang lain. Vaksin polivalen yang berisi $\mathrm{E}$. ictaluri dan F. columnare bakterin mempunyai efektivitas yang rendah dan penggunaan isolat live attenuated merupakan hal yang baru dan sangat menjanjikan untuk vaksin polivalen di masa mendatang.

Vaksin virus pertama diproduksi oleh Czechoslovakian Company (Bioveta) pada tahun 1982 (Ellis, 1988). Vaksin terhadap Carp Rhabdovirus penyebab Spring Viraemia of Carp (SVC), ini terdiri atas dua strain virus SVC yang diinaktivasi dan diemulsikan dalam minyak serta diaplikasikan melalui injeksi. Vaksin inactivated terhadap penyakit pancreas (PD, disebabkan oleh aquatic al phavirus) sudah tersedia di Irlandia dan vaksin terhadap Infectious Salmon Anemia (ISA, disebabkan oleh Orthomyxovirus) juga sudah tersedia di Canada dan USA, tetapi tidak di Eropa karena negara tersebut memberlakukan legislasi preventif yaitu kebijakan stamping-out (pemusnahan) (David, 2008). Selama lebih dari 30 tahun, sudah banyak penelitian untuk menciptakan vaksin yang efektif dengan menggunakan pendekatan konvensional yaitu vaksin killed dan live. Secara studi laboratoris, keduanya mampu menimbulkan proteksi yang baik, tetapi kerugiannya, vaksin live tidak 
aman digunakan di lapang sedang vaksin inactivated membutuhkan dosis yang tinggi. Pada saat ini, vaksin DNA merupakan vaksin protektif jika digunakan pada dosis kecil ( $<10 \mathrm{ng}$ pada benih trout) dan efektif sampai dua tahun post-vaksinasi (David, 2008).

Penyakit parasiter seperti amoebic gill disease, white spot disease, whirling disease, proliferative kidney disease banyak menimbulkan masalah dalam budidaya ikan, tetapi belum ada vaksin komersial yang tersedia untuk melawan penyakit-penyakit tersebut. Salah satu penyebabnya adalah, pemanenan parasit yang digunakan untuk vaksin killed dan live lebih mahal dibandingkan pada virus, karena dibutuhkan populasi inang daripada kultur jaringan. Di samping membutuhkan biaya besar, penggunaan inang alami sebagai tempat hidup dan perkembangbiakan parasit menimbulkan berbagai permasalahan. Tabel 1 menyajikan jenis-jenis penyakit pada ikan dan ada tidaknya vaksin komersial di pasaran untuk proteksi terhadap penyakitpenyakit tersebut.

Selama ini, prospek penelitian tentang vaksin pada ikan masih terbuka lebar terutama vaksin untuk penyakit parasiter. Peneliti-peneliti berikut ini melakukan riset tentang vaksin dan efektivitasnya, Gilad et al. (2001) melakukan vaksinasi pada large stock dan ternyata tidak dapat mengeliminasi patogen. Vaksinasi memang secara drastis dapat menurunkan mortalitas, tetapi patogen masih ada atau tertinggal pada ikan dan lingkungannya. Sebagai konsekuensi adanya tekanan selektif yang dipicu oleh vaksinasi menyebabkan munculnya serotipe lain untuk mengambil alih. Pasnik et al. (2005) telah meneliti efektivitas vaksin S. agalactiae menggunakan ECP (extracellular product) dan whole cell dari S. agalactiae yang diinaktivasi dengan formalin dan disimpan pada suhu $4^{\circ} \mathrm{C}$ selama satu tahun. Hasil yang diperoleh, ECP S. agalactiae ternyata tidak dapat melindungi dan tetap dapat menyebabkan morbiditas dan mortalitas pada ikan-ikan yang divaksinasi dengan relative percentage survival-nya 29.

\section{KESIMPULAN}

Vaksin polivalen sangat dibutuhkan karena dapat memberikan proteksi terhadap lebih dari dua penyakit sekaligus dan akan mengurangi stres pada ikan serta menghemat biaya di segala bidang.

Pembuatan vaksin polivalen memerlukan kompatibilitas kondisi fisik, kimia, dan biologis dari komponen aktif vaksin, ajuvant, excipients, dan preservatif.

Pengembangan vaksin membutuhkan rangkaian penelitian laboratoris meliputi uji pre-formulasi, uji stabilitas, studi toksikologi, dan uji klinis.

\section{DAFTAR ACUAN}

Ellis A.E. 1988. Fish Vaccination. Academic Press. 247 pp.

David, W.S. 2008. Combining Vaccines: Does It Make Sense and Does It Work? Vaccine Evaluation Center UBC, Vancouver, B.C. Presentation at 14 Th Child Health Symposium, March, 12, 2008.

Gilad, B., Zlotkin, A., Hurvits, A., Evans, D.L., \& Eldar, A. 2001. Recovery of $S$. iniae From Diseased Fish Previously Vaccinated With A Streptococcus Vaccine. Appl. Environ. Microbiol. August 67(8): 3756-3758.

Néstor S.E., Cardoso, D., Martínez, E., Herrera, Y., Cosme, K., Díaz, P.A., Prieto, Y.C., Núñez, Z., Izquierdo, M., Mayo, O., Pérez, J., \& Hidalgo, L.C. 2006. Trivac HB: A Cuban Polyvalent Vaccine. Biotecnología Aplicada, 23(2): 165-170.

Pasnik, D.J., Evans, J.J., Panangala, V.S., Klesius, P.H., Shelby, R.A., \& Shoemaker, C.A. 2005. Antigenicity of Streptococcus agalactiae Extracelluler Products and Vaccine Efficacy. Journal of Fish Diseases, 28(4): 205212.

Sommerset, I., B. Krossoy, E. Biering, P. Frost. 2005. Vaccines for Fish in Aquaculture. Expert Rev. Vaccine, 4(1): 89-101. 